\section{Use of the HLA-B leader to optimize cord blood transplantation}

Effie W. Petersdorf, ${ }^{1,2}$ Ted Gooley, ${ }^{1}$ Fernanda Volt, ${ }^{3}$ Chantal Kenzey, ${ }^{3}$ Alejandro Madrigal, ${ }^{4}$ Caroline McKallor, ${ }^{1}$ Sergio Querol, ${ }^{5}$ Hanadi Rafii, ${ }^{3}$ Vanderson Rocha, ${ }^{3,6}$ Ryad Tamouza, ${ }^{3,7}$ Christian Chabannon, ${ }^{8,9}$ Annalisa Ruggeri $i^{3,9,10}$ and Eliane Gluckman ${ }^{3,11}$

${ }^{1}$ Division of Clinical Research, Fred Hutchinson Cancer Research Center, Seattle, WA, USA; ${ }^{2}$ Department of Medicine, University of Washington, Seattle, WA, USA; ${ }^{3}$ Eurocord, Hôpital Saint Louis APHP, Institut de Recherche de Saint-Louis (IRSL) EA3518, Université de Paris, Paris, France; ${ }^{4}$ University College London Cancer Institute, Royal Free Campus, London, UK; ${ }^{5}$ Cell Therapy Services, Catalan Blood and Tissue Bank, Barcelona, Spain, ${ }^{6} \mathrm{Hospital}$ das Clínicas and LIM31, Faculty of Medicine University of São Paulo, Brazil; " INSERM U955, CHU Henri Mondor, Créteil, France, ${ }^{8}$ Institut PaoliCalmettes, INSERM CBT1409, Marseille, France; ${ }^{9}$ Cellular Therapy and Immunobiology Working Party of the European Society for Blood and Marrow Transplantation, Leiden, the Netherlands; ${ }^{10} \mathrm{Hematology}$ and Bone Marrow Transplant Unit, IRCCS San Raffaele Scientific Institute, Milan, Italy and ${ }^{11}$ Monacord, International Observatory on Sickle Cell Disease, Centre Scientifique de Monaco, Monaco

\section{ABSTRACT}

ord blood transplantation (CBT) can cure life-threatening blood disorders. The HLA-B leader affects the success of unrelated donor transplantation but its role in CBT is unknown. We tested the hypothesis that the HLA-B leader influences CBT outcomes in unrelated single-unit cord blood transplants performed by Eurocord/European Blood and Marrow Transplant (EBMT) centers between 1990 and 2018 with data reported to Eurocord. Among 4,822 transplants, 2,178 had one HLA-B mismatch of which 1,013 were HLA$A$ and HLA-A and -DRB1 matched. The leader (methionine [M] or threonine [T]) was determined for each HLA-B allele in patients and units to define the genotype. Among single HLA-B-mismatched transplants, the patient/unit mismatched alleles were defined as leader-matched if they encoded the same leader, or leader-mismatched if they encoded different leaders; the leader encoded by the matched (shared) allele was determined. The risks of graft-versus-host disease, relapse, non-relapse mortality and overall mortality were estimated for various leader-defined groups using multi-variable regression models. Among the 1,013 HLA-A and -DRB1-matched transplants with one HLA-B mismatch, increasing numbers of cord blood unit M-leader alleles was associated with increased risk of relapse (hazard ratio [HR] for each increase in one $\mathrm{M}$ leader allele 1.30, 95\% Confidence Interval [CI]: 1.05-1.60, $P=0.02$ ). Furthermore, leader mismatching together with an M-leader of the shared HLA-B allele lowered non-relapse mortality (HR 0.44, 95\% CI: 0.23-0.81; $P=0.009)$ relative to leader matching and a shared T-leader allele. The HLA-B leader may inform relapse and non-relapse mortality risk after CBT. Future patients might benefit from the appropriate selection of units that consider the leader.

\section{Introduction}

Cord blood transplantation (CBT) offers curative therapy for life-threatening blood disorders. Its distinct advantages are 2-fold. Similar to haploidentical donor transplantation, the less stringent level of histocompatibility required between the patient and the cord blood unit is an asset for patients of diverse ancestry who lack HLA-matched peripheral blood stem cell and marrow donors. ${ }^{1-11}$ Compared to other sources of allogeneic stem cells, a unique benefit of cord blood transplantation is the avoidance of risks to the donor. The lower risk of severe acute and
Ferrata Storti Foundation

Haematologica 2021

Volume 106(12):3107-3114

\section{Correspondence:}

EFFIE W. PETERSDORF

epetersd@fredhutch.org

Received: June 23, 2020.

Accepted: October 15, 2020.

Pre-published: October 29, 2020.

https://doi.org/10.3324/haematol.2020.264424

(C)2021 Ferrata Storti Foundation

Material published in Haematologica is covered by copyright. All rights are reserved to the Ferrata Storti Foundation. Use of published material is allowed under the following terms and conditions:

https://creativecommons.org/licenses/by-nc/4.0/legalcode. Copies of published material are allowed for personal or internal use. Sharing published material for non-commercial purposes is subject to the following conditions:

https://creativecommons.org/licenses/by-nc/4.0/legalcode, sect. 3. Reproducing and sharing published material for commercial purposes is not allowed without permission in writing from the publisher. 
chronic graft-versus-host disease (GvHD) in cord blood transplantation compared to other allograft sources is related to the limited numbers of mature donor $\mathrm{T}$ cells in naïve cord blood grafts. ${ }^{6}$ Despite lower rates of GvHD, disease recurrence after cord blood transplantation is not

Table 1. Demographics of the study population. The effect of the HLA$B$ leader in clinical outcome was assessed among the base population of 4,822 single cord blood unit transplants, the subset of 2,178 transplants with one HLA-B mismatch, and the subset of 1,013 HLA-A and -DRB1-matched transplants with one HLA-B mismatch.

\begin{tabular}{|c|c|c|c|}
\hline \multirow[t]{2}{*}{ Characteristics } & \multicolumn{3}{|c|}{ Single cord blood unit transplants } \\
\hline & $\begin{array}{c}\text { Base populatior } \\
n=4,822\end{array}$ & $\begin{array}{l}\text { One } \\
\text { HIA-B } \\
\text { mismatch } \\
n=2,178\end{array}$ & $\begin{array}{l}\text { HIA-A and } \\
\text { DRB1- } \\
\text { matched } \\
\text { with one } \\
\text { IA-B mismatch } \\
\text { n = 1,013 }\end{array}$ \\
\hline $\begin{array}{l}\text { Patient age, average yrs } \\
\text { (range) }\end{array}$ & $\begin{array}{c}17.1 \\
(0.1-70.7)\end{array}$ & $\begin{array}{c}21.3 \\
(0.1-70.7)\end{array}$ & $\begin{array}{c}14.5 \\
(0.1-69.0)\end{array}$ \\
\hline $\begin{array}{l}\text { Patient sex, n (\%) } \\
\text { Female } \\
\text { Male } \\
\text { Missing or N/A }\end{array}$ & $\begin{array}{l}2,152(45 \%) \\
2,649(55 \%) \\
21(0 \%)\end{array}$ & $\begin{array}{c}986(45 \%) \\
1,189(55 \%) \\
3(0 \%)\end{array}$ & $\begin{array}{c}461(46 \%) \\
551(54 \%) \\
1(0 \%)\end{array}$ \\
\hline $\begin{array}{l}\text { Disease type, n (\%) } \\
\text { Malignant } \\
\text { Non-malignant }\end{array}$ & $\begin{array}{l}3,577(74 \%) \\
1,245(26 \%)\end{array}$ & $\begin{array}{l}1,769(81 \%) \\
409(19 \%)\end{array}$ & $\begin{array}{l}766(76 \%) \\
247(24 \%)\end{array}$ \\
\hline $\begin{array}{l}\text { Disease status at transplantati } \\
\text { low } \\
\text { intermediate } \\
\text { high } \\
\text { Missing or N/A }\end{array}$ & $\begin{array}{c}\text { ation *, } \mathrm{n}(\%) \\
1,189(25 \%) \\
1,308(27 \%) \\
735(15 \%) \\
1,590(33 \%)\end{array}$ & $\begin{array}{l}606(28 \%) \\
600(28 \%) \\
404(19 \%) \\
568(26 \%)\end{array}$ & $\begin{array}{l}258(25 \%) \\
280(28 \%) \\
165(16 \%) \\
310(31 \%)\end{array}$ \\
\hline $\begin{array}{l}\text { Patient CMV serology, n (\%) } \\
\text { negative } \\
\text { positive } \\
\text { Missing or N/A }\end{array}$ & $\begin{array}{c}1,900(39 \%) \\
2,599(54 \%) \\
323(6 \%)\end{array}$ & $\begin{array}{c}784(36 \%) \\
1,258(58 \%) \\
136(6 \%)\end{array}$ & $\begin{array}{c}381(38 \%) \\
567(56 \%) \\
65(6 \%)\end{array}$ \\
\hline $\begin{array}{l}\text { HLA Matching, n (\%) } \\
6 / 6 \\
5 / 6 \\
4 / 6 \\
\text { Other }\end{array}$ & $\begin{array}{c}934(19 \%) \\
2,233(46 \%) \\
1,536(32 \%) \\
119(2 \%)\end{array}$ & $\begin{array}{c}0(0 \%) \\
1,013(47 \%) \\
1,110(51 \%) \\
55(3 \%)\end{array}$ & $\begin{array}{c}0(0 \%) \\
1,013(100 \%) \\
0(0 \%) \\
0(0 \%)\end{array}$ \\
\hline $\begin{array}{l}\text { Year of transplantation, n (\%) } \\
\leq 2005 \\
>2005\end{array}$ & $\begin{array}{l}1269(26 \%) \\
3,553(74 \%)\end{array}$ & $\begin{array}{c}595(27 \%) \\
1,583(73 \%)\end{array}$ & $\begin{array}{l}302(30 \%) \\
711(70 \%)\end{array}$ \\
\hline $\begin{array}{l}\text { Transplant type, n (\%) } \\
\text { MAC } \\
\text { RIC } \\
\text { Missing or N/A }\end{array}$ & $\begin{array}{c}3,558(74 \%) \\
1,088(23 \%) \\
176(4 \%)\end{array}$ & $\begin{array}{c}1,578(72 \%) \\
537(25 \%) \\
63(3 \%)\end{array}$ & $\begin{aligned} 760 & (75 \%) \\
222 & (22 \%) \\
31 & (3 \%)\end{aligned}$ \\
\hline $\begin{array}{l}\text { Total body irradiation, n (\%) } \\
\text { no } \\
\text { yes } \\
\text { Missing or N/A }\end{array}$ & $\begin{array}{c}2,988(62 \%) \\
1,531(32 \%) \\
303(6 \%)\end{array}$ & $\begin{array}{l}1,230(56 \%) \\
812(37 \%) \\
136(6 \%)\end{array}$ & $\begin{array}{c}599(59 \%) \\
378(37 \%) \\
36(4 \%)\end{array}$ \\
\hline $\begin{array}{l}\text { Use of ATG, n (\%) } \\
\text { no } \\
\text { yes }\end{array}$ & $\begin{array}{l}1,454(30 \%) \\
3,368(70 \%)\end{array}$ & $\begin{array}{c}645(30 \%) \\
1,533(70 \%)\end{array}$ & $\begin{array}{l}288(28 \%) \\
725(72 \%)\end{array}$ \\
\hline $\begin{array}{l}\text { Total nucleated cells infused, } \\
\text { median (range) }\end{array}$ & $\begin{array}{c}5.51 \\
(0.20-94.9) \\
\end{array}$ & $\begin{array}{c}4.91 \\
(0.37-81.4) \\
\end{array}$ & $\begin{array}{c}6.24 \\
(0.38-81.4) \\
\end{array}$ \\
\hline $\begin{array}{l}\text { *Disease status at transplantation: lo } \\
\text { disease [HD] in complete remissior } \\
\text { leukemia [CML] in chronic phase; } n \\
\text { [RA] with or without ring sideroblast } \\
\text { 1); intermediate risk (NHL or HD in } \\
\text { phase; MDS-RAEB-2; RCMD; RCMD-RS } \\
\text { fiable MDS); high risk (NHL or HD un } \\
\text { leukemia untreated, refractory or rela } \\
\text { leukema; plasma cell disorders; chr } \\
\text { leukemia). N/A: not available. }\end{array}$ & $\begin{array}{l}\text { low risk (non-Hodg } \\
\text { ion [CR] 1; acute le } \\
\text {; myelodysplastic sy } \\
\text { asts [RS]; refractory } \\
\text { in } \geq \text { CR2; acute leuke } \\
\text { RS; MDS associated } \\
\text { untreated, refractory, } \\
\text { elapse; CML in blasti } \\
\text { chronic lymphocytic }\end{array}$ & $\begin{array}{l}\text { lgkin lymphoma } \\
\text { leukemia in CR } \\
\text { syndrome [MDS } \\
\text { z anemia with ex } \\
\text { kemia in } \geq C R 2 ; \\
\text { d with isolated d } \\
\text { ry,partial remissi } \\
\text { tic crisis; MDS tr } \\
\text { ic leukemia/lym }\end{array}$ & $\begin{array}{l}\text { [NHL] or Hodgkin } \\
\text { R1; chronic myeloid } \\
\text { 1]-refractory anemia } \\
\text { xcess blasts [RAEB]- } \\
\text { CML in accelerated } \\
\text { del [5q], or unclassi- } \\
\text { ion or relapse; acute } \\
\text { ransformed in acute } \\
\text { nphoma; secondary }\end{array}$ \\
\hline
\end{tabular}

necessarily higher than that observed with other allograft sources. ${ }^{12}$ The precise immunological pathways that lead to these clinical outcomes remain to be elucidated; however, the innate immune system is an attractive mechanism because natural killer (NK) cells are the earliest population of cells to reconstitute after cord blood transplantation. ${ }^{13-16}$ Beneficial NK-associated responses have been demonstrated in transplantation and the extent to which they can be leveraged to lower posttransplant disease recurrence remains an important area of clinical investigation. $^{8-10,17,18}$

A basic premise of transplantation is HLA compatibility between the graft and the patient. Recent evidence in unrelated donor transplantation implicates the HLA-B leader in graft-versus-host responses and demonstrates the importance of HLA that goes beyond the classic model based on matching under the framework of antigen presentation. ${ }^{19,20}$ As a peptide presented by classical class I molecules, the leader provides an antigenic stimulus to $\mathrm{T}$ cells. As a peptide that facilitates the cell-surface expression of HLA-E, it also influences NK allorecognition. The HLA-B leader is distinguished from the leaders of other classical class I genes due to a dimorphism that leads to peptides with methionine $(M)$ or threonine $(T)$ at the second position of the leader peptide. ${ }^{21}$ Leader-associated differential expression of HLA-E influences inhibitory NKG2A- and to a lesser extent activating NKG2C-mediated responses. ${ }^{22}$ In HIV-AIDs, the dimorphic HLA-B leader influences progression of the disease depending on the strength of HLA-E/NKG2 responses. ${ }^{23,24}$

Cord blood transplants are a unique population of pairs who may be mismatched concurrently at multiple HLA genetic loci and differ from unrelated donor transplants in whom the total number of HLA disparities must be limited to prevent life-threatening complications. ${ }^{19}$ The contribution of an HLA mismatch to clinical outcomes after cord blood and unrelated donor transplantation may depend on the specific gene(s) that is mismatched and on additive effects of multi-locus mismatching across the HLA region. ${ }^{19,25-27}$ Furthermore, the effect of the HLA-B leader on specific outcomes may depend on the mismatched HLA locus. ${ }^{19,20}$ The current study was designed to address an unmet need in cord blood transplantation for a better understanding of the clinical significance of the HLA barrier. We tested the hypothesis that the HLA-B leader informs outcome in a large, well-characterized cohort of single-unit cord blood transplants, beginning with an evaluation of all transplants and subsequently of transplants defined by matching at HLA-A, -B and -DRB1, the classic determinants of cord blood transplant outcomes. This hierarchy permitted the evaluation of the effect of the leader while minimizing contributions from other mismatched loci. The results may have important implications for future patients and advance understanding of the immunobiology of relapse.

\section{Methods}

\section{Study population and design}

The study population included 4,822 patients who received a single-unit unrelated cord blood transplant in an Eurocord/European Blood and Marrow Transplant (EBMT) center for the treatment of a blood disorder between 1990 and 2018 (Table 1; Online Supplementary Table S1). Data were collected by 


\section{Single-Unit Unrelated Cord Blood Transplants $\mathrm{N}=4,822$ \\ One HLA-B Mismatch $\mathrm{N}=2,178$}

I

HLA-A and -DRB1-Matched $\mathrm{N}=1,013$
Figure 1. The clinical significance of the HLA-B leader was evaluated in cord blood transplantation according to HLA matching, leader genotype, and leader-matching. The study population consisted of 4,822 single-unit unrelated cord blood transplantations. The clinical significance of the HLA-B leader in outcome was analyzed in the entire population, among transplants with one HLA-B mismatch (regardless of HLA mismatching elsewhere), and in HLA-A and DRB1-matched transplants with one HLA-B mismatch. The impact of the HLA-B leader was analyzed according to the cord blood unit's leader genotype (left pie), the leader match status (middle pie), and the leader match status together with the leader of the shared antigen (right pie).

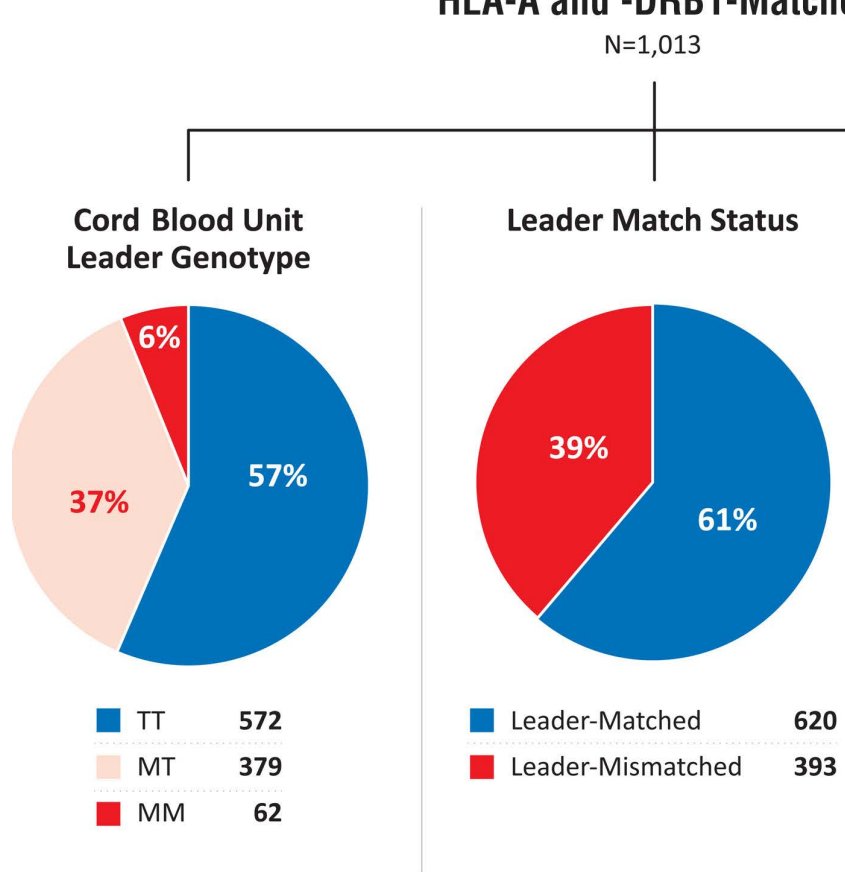

Eurocord through the EBMT/Promise database following national and Joint Accreditation Committee International Society for Cellular Therapy - Europe \& EBMT (JACIE) guidelines, and shared according to agreements between Eurocord and the Fred Hutchinson Cancer Research Center.

We previously observed a strong effect of the HLA-B leader in single-locus HLA-B-mismatched unrelated transplants who were matched at HLA-A, -C, -DRB1 and -DOB1, an effect that neither depends on HLA-C KIR ligands nor on the level of typing for HLA-A, -C, -DRB1 or -DOB1 allele and antigen mismatches. ${ }^{19}$ Since cord blood units are selected on the basis of HLA-A, B, -DRB1 and most transplants in the current study lack highresolution typing including HLA-C, models did not adjust for these factors. We tested the hypothesis that the HLA-B leader dimorphism informs clinical outcome by examining three groups defined by their match status at HLA-A, -B and -DRB1: i) the entire study population of 4,822 patients (Online Supplementary Table S2); ii) a subset of 2,178 transplants with one allele or antigen HLA-B mismatch regardless of mismatching elsewhere to examine whether the leader provides information on well-tolerated HLA-B mismatches (Online Supplementary Table S3), and iii) a subset of 1,013 HLA-A and -DRB1-matched transplants with one allele or antigen HLA-B mismatch which permitted the potential effects of the leader to be examined without disparity from HLA-A and -DRB1 (Online Supplementary Table S4; Figure 1).

\section{Study oversight}

Protocols were approved by the Institutional Review Boards of Eurocord and the National Institutes of Health Office for Human Research Protections. The funding agencies had no role in the study design, data collection and analysis, the decision to submit the manuscript for publication, or the preparation of the manuscript.

\section{HLA typing}

Classical HLA alleles were genotyped in the study cohort according to standard criteria and individual transplant center guidelines. ${ }^{25-27}$ The rs1050458 single nucleotide polymorphism in exon one is defined for World Health Organization-recognized HLA-B alleles and antigens. ${ }^{28}$ The one-to-one relationship between the leader dimorphism and HLA-B allele and antigen and has been previously confirmed, permitting the assignment of methionine (M) (rs1050458T) or threonine (T) (rs1050458C) leader to each patient and cord blood unit based on typing performed at the time of transplantation (Figure 2).$^{19}$ The leader genotype (TT, MT or MM) was determined for each patient and each cord blood unit. When the patient and cord blood unit are HLA-B-matched, they have, by definition, the same leader genotype. Transplants mismatched for one HLA-B allele were defined as leader-matched when the patient's and unit's mismatched alleles were both $M$ or both T leader. Single HLA-B mismatches were defined as leadermismatched when the patient's and unit's mismatched alleles had different leaders ( $M$ leader in the patient's mismatched allele with $T$ leader in the unit's mismatched allele, or vice versa). Among single HLA-B-mismatched transplants, the leader of the matched (shared) allele between the patient and unit was determined ( $M$ or T). For single HLA-B-mismatched transplants, leader match status was combined with the leader of the shared matched allele to define four mutually exclusive groups: leader-matched/share $\mathrm{T}$; leader-matched/share $\mathrm{M}$; leader-mismatched/share $\mathrm{T}$, and leadermismatched/share M (Figure 2). 
Table 2 Leader match status and clinical Outcome in 1,013 single HLA-B-mismatched cord blood transplantations (matched at HLA-A and -DRB1). A total of 814 patients are evaluable for relapse and non-relapse mortality.

\begin{tabular}{|c|c|c|c|c|}
\hline Clinical Endpoint & Group* & Odds Ratio or Hazard Ratio & $95 \%$ Confidence Interval & $P$ \\
\hline \multirow[t]{2}{*}{ Grades II-IV acute GvHD } & $\begin{array}{l}\text { Leader-matched } \\
(220 / 604=36 \%)\end{array}$ & 1 & - & - \\
\hline & $\begin{array}{l}\text { Leader mismatched } \\
\quad(138 / 384=36 \%)\end{array}$ & 0.98 & $0.75-1.29$ & 0.89 \\
\hline \multirow[t]{2}{*}{ Relapse } & $\begin{array}{l}\text { Leader-matched } \\
(132 / 498=27 \%)\end{array}$ & 1 & - & - \\
\hline & $\begin{array}{l}\text { Leader-mismatched } \\
\quad(92 / 316=29 \%)\end{array}$ & 1.02 & $0.77-1.35$ & 0.87 \\
\hline \multirow[t]{2}{*}{ Mortality } & $\begin{array}{l}\text { Leader-matched } \\
(332 / 620=54 \%)\end{array}$ & 1 & - & - \\
\hline & $\begin{array}{l}\text { Leader-mismatched } \\
\quad(182 / 393=46 \%)\end{array}$ & 0.85 & $0.71-1.02$ & 0.08 \\
\hline \multirow[t]{2}{*}{ Non-relapse mortality } & $\begin{array}{l}\text { Leader-matched } \\
(168 / 498=34 \%)\end{array}$ & 1 & - & $-\mathrm{a}$ \\
\hline & $\begin{array}{l}\text { Leader-mismatched } \\
(79 / 316=25 \%)\end{array}$ & 0.72 & $0.55-0.94$ & 0.02 \\
\hline
\end{tabular}

*The numbers refer to the number of patients who developed the clinical endpoint out of the total number of evaluable patients (for whom data for the clinical endpoint was available). GvHD: graft-versus-host disease.

\section{Statistical analysis}

We examined the association of the HLA-B leader genotype and leader matching with grades II-IV acute GvHD, relapse, death not preceded by relapse, disease-free survival and overall mortality. Logistic regression was used to assess associations with acute GvHD. For all other endpoints, Cox regression models were fit to compare the hazards or cause-specific hazards of failure, as appropriate, between HLA-B leader groups, and patients who did not fail by last contact or who failed from a competing risk were censored at last contact or at the time of the competing risk (as appropriate). Relapse was studied for patients with malignant disorders. Regression models were adjusted for patient age, year of transplantation, disease risk at transplantation (low, intermediate, high, non-malignant), total nucleated cell dose, use of anti-thymocyte globulin, intensity of the conditioning regimen (reduced-intensity versus ablative), use of total body irradiation, patient cytomegalovirus serologic status, and number of mismatches at HLA-A and -DRB1. Various interactions, as detailed in the Results, were examined by including appropriate factors in these regression models. Covariates with missing data were included in models by creating an additional category to reflect the missing value of the appropriate covariate. If outcome data were missing for a particular patient, such a patient was excluded from the appropriate regression analysis. Two-sided $P$-values from Cox regression models were obtained from the Wald test. Several comparisons were made, all focused on refinements of the concept of leader matching versus leader mismatching. No adjustments were made to the $P$-values associated with the fitted regression models, although the impact of multiple comparisons is reduced because the examined endpoints are correlated with one another. For individual models with more than two categories, global tests of significance were also conducted.

\section{Results}

\section{HLA-B leader genotype and leader matching}

The frequency of leader genotypes among patients (293 [6\%] MM; ,1724 [36\%] MT; 2,805 [58\%] TT) were similar to the frequencies among the cord blood units (295 [6\%] MM; 1828 [38\%] MT; 2699 [56\%] TT) and HLA-matched and HLA-mismatched unrelated donor transplants (Figure 1). ${ }^{19,20}$ Among the entire study population, $81 \%$ were leader-matched and $19 \%$ were leader-mismatched. The distribution among transplants with one HLA-B mismatch was 1,027 (47\%) leader-matched/share T, 311 (14\%) leader-matched/share M, 640 (29\%) leader-mismatched/share T, and 200 (9\%) leader-mismatched/share M.

\section{Leader genotype and clinical outcome}

We tested the hypothesis that the HLA-B leader genotype of the patient and/or the unit may influence the clinical outcome by examining the impact of the patient's leader genotype separately from the cord blood unit's leader genotype among the entire population of 4,822 transplants. Although the leader genotype of the patient did not exhibit obvious correlation with clinical outcome (Online Supplementary Tables S2, S3 and S4), the cord blood unit's leader genotype was associated with the risk of relapse among the 1,013 HLA-A and -DRB1-matched transplants with one HLA-B allele mismatch (Online Supplementary Table S4). In this subgroup, transplantation from MT cord blood units had an estimated hazard ratio (HR) of 1.29 (95\% Confidence Interval [CI]: 0.96-1.73) relative to TT cord blood units and MM had an estimated HR of $1.69(95 \%$ CI: 1.03-2.75) for relapse relative to TT. The probability of observing these or more extreme differences under the null hypothesis that the risks of relapse are identical across the three leader genotype groups is 0.06 . In addition, if one models the number of $M$ leaders as a continuous linear variable ranging from 0 to 2 (addressing the possible existence of an increase in risk with increasing number of $\mathrm{M}$ leader alleles), the probability of a difference in relapse risk that is as extreme or more extreme than what was observed is 0.02 (HR 1.30 for each increase of one M leader allele, 95\% CI: 1.05-1.60). Interestingly, transplantation of MT and MM units did not show a clear impact on GvHD risk but MM units may be associated with a lower risk of non-relapse mortality (HR 0.46, 95\% CI: 0.23-0.95; Online Supplementary Table S4), although the global test of significance of the unit leader yielded $P=0.11$.

\section{Leader matching and clinical outcome}

The dimorphism of the HLA-B leader defines two lineages of HLA-B alleles. ${ }^{19}$ In HLA-B-mismatched transplantation, the patient's and cord blood unit's mismatched alleles may be from the same (leader-matched) or different (leader-mismatched) lineage. The impact of leader matching was examined in the 1,013 HLA-A and -DRB1-matched transplants with a single HLA-B mismatch. 
Table 3. Impact of leader match status and leader of the shared allotype on clinical outcome in 1,013 single HLA-B-mismatched cord blood transplantations (matched at HLA-A and -DRB1). A total of 814 patients are evaluable for relapse and non-relapse mortality.

\begin{tabular}{|c|c|c|c|c|}
\hline Clinical Endpoint & $\begin{array}{l}\text { Leader Match Status/ } \\
\text { Leader of Shared Antigen* }\end{array}$ & Odds Ratio or Hazard Ratio & 95\% Confidence Interval & $\begin{array}{c}P \\
\text { (Global P) }\end{array}$ \\
\hline \multirow[t]{4}{*}{ Grades II-IV acute GvHD } & $\begin{array}{c}\text { Leader-matched/T } \\
(169 / 464=36 \%)\end{array}$ & 1 & - & (global P 0.37) \\
\hline & $\begin{array}{l}\text { Leader-matched/M } \\
\quad(51 / 140=36 \%)\end{array}$ & 1.05 & $0.70-1.57$ & 0.83 \\
\hline & $\begin{array}{l}\text { Leader-mismatched/T } \\
(100 / 299=33 \%)\end{array}$ & 0.90 & $0.66-1.23$ & 0.49 \\
\hline & $\begin{array}{l}\text { Leader-mismatched/M } \\
\quad(38 / 85=45 \%)\end{array}$ & 1.42 & $0.87-2.29$ & 0.16 \\
\hline \multirow[t]{4}{*}{ Relapse } & $\begin{array}{l}\text { Leader-matched/T } \\
(98 / 386=25 \%)\end{array}$ & 1 & - & (global $P 0.94$ ) \\
\hline & $\begin{array}{c}\text { Leader-matched/M } \\
(34 / 112=30 \%)\end{array}$ & 1.14 & $0.76-1.74$ & 0.54 \\
\hline & $\begin{array}{l}\text { Leader-mismatched/T } \\
\text { (70/248=28\%) }\end{array}$ & 1.03 & $0.75-1.43$ & 0.84 \\
\hline & $\begin{array}{l}\text { Leader-mismatched/M } \\
\quad(22 / 68=32 \%)\end{array}$ & 1.08 & $0.66-1.77$ & 0.77 \\
\hline \multirow[t]{4}{*}{ Mortality } & $\begin{array}{l}\text { Leader-matched/T } \\
(248 / 479=52 \%)\end{array}$ & 1 & - & (global $P 0.10$ ) \\
\hline & $\begin{array}{l}\text { Leader-matched/M } \\
\quad(84 / 141=60 \%)\end{array}$ & 1.15 & $0.90-1.48$ & 0.26 \\
\hline & $\begin{array}{l}\text { Leader-mismatched/T } \\
\quad(146 / 306=48 \%)\end{array}$ & 0.94 & $0.76-1.15$ & 0.52 \\
\hline & $\begin{array}{l}\text { Leader-mismatched/M } \\
\quad(36 / 87=41 \%)\end{array}$ & 0.71 & $0.50-1.01$ & 0.06 \\
\hline \multirow[t]{4}{*}{ Non-relapse mortality } & $\begin{array}{l}\text { Leader-matched } / T \\
(127 / 386=33 \%)\end{array}$ & 1 & - & (global $P 0.02$ ) \\
\hline & $\begin{array}{l}\text { Leader-matched/M } \\
\quad(41 / 112=37 \%)\end{array}$ & 1.18 & $0.82-1.69$ & 0.37 \\
\hline & $\begin{array}{l}\text { Leader-mismatched/T } \\
\qquad(68 / 248=27 \%)\end{array}$ & 0.84 & $0.62-1.13$ & 0.25 \\
\hline & $\begin{array}{l}\text { Leader-mismatched/M } \\
(11 / 68=16 \%)\end{array}$ & 0.44 & $0.23-0.81$ & 0.009 \\
\hline
\end{tabular}

*The numbers refer to the number of patients who developed the clinical endpoint out of the total number of evaluable patients (for whom data for the clinical endpoint was available). GvHD: graft-versus-host disease.

Relative to leader-matched transplants, leader-mismatched transplants had lower non-relapse mortality (HR 0.72, 95\% CI: $0.55-$ 0.94; $P=0.02$ ) (Table 2); overall mortality was lower but not statistically significantly so.

When the leader of the shared HLA-B allele is considered alongside the leader match status, there was a statistically significant difference in the risk of non-relapse mortality across the resultant four groups (Table 3 , global $P=0.02$ ). This result was largely driven by transplantation from leader-mismatched units that share an $\mathrm{M}$ leader allele with the patient compared to transplantation from leader-matched units that share a T leader allele (Table 3; HR 0.44, $95 \%$ CI: $0.23-0.81 ; P=0.009)$. Not surprisingly, the comparison of overall mortality for these same groups showed a difference in the same direction as that for non-relapse mortality; however, the magnitude of the difference was smaller and was not statistically significant) (Table 3). Other pairwise comparisons of non-relapse mortality that may be of particular interest include leader-mismatched units that share a $\mathrm{T}$ leader allele with the patient compared to transplantation from leader-mismatched units that share an $\mathrm{M}$ leader allele (HR 1.92, 95\% CI: 1.01-3.65; $P=0.05$ ) and leadermatched units that share an $\mathrm{M}$ leader allele with the patient compared to transplantation from leader-mismatched units that share an M leader allele (HR 2.70, 95\% CI: 1.38-5.29; $P=0.004)$.

In summary, the HLA-B leader genotype of the cord blood unit may inform outcome after transplantation from HLA-B-mismatched units. Among patients transplanted from HLA-A and
DRB1-matched units with one HLA-B mismatch, leader mismatching and presence of a matched M-leader allele may be associated with lower non-relapse mortality. Units with MT and MM leader genotypes may be associated with a higher risk of relapse; however, the higher relapse risk conferred by the genotype together with lower non-relapse mortality associated with leader mismatching appeared to have no demonstrable impact on overall survival.

\section{Discussion}

An unmet need of CBT is a better understanding of the factors that influence outcome. The current study was designed to test a series of novel hypotheses regarding the significance of the dimorphic HLA-B leader in CBT. Interest in the HLA-B leader is founded on its pivotal role in both adaptive and innate immune pathways. A role for the HLA-B leader in HLA-B-mismatched unrelated donor transplantation in GvHD provides an approach for understanding the immunogenicity of $\mathrm{M}$ and $\mathrm{T}$ leader alleles in a way that may bridge T- with NK-cell biology.

The effects of HLA mismatching are well-tolerated in CBT, permitting a higher overall degree of disparity between the patient and cord blood unit. The majority of CBT are mismatched at HLA-B. With over 7,000 known 
A

M AND T LEADER FOR HLA-B ALLELES

T Leader Alleles

$\begin{array}{lllll}\text { B13 } & \text { B45 } & \text { B55 } & \text { B63 } & : \\ \text { B15 } & \text { B46 } & \text { B56 } & \text { B70 } & : \\ \text { B18 } & \text { B47 } & \text { B57 } & \text { B71 } & : \\ \text { B27 } & \text { B49 } & \text { B58 } & \text { B72 } & : \\ \text { B35 } & \text { B50 } & \text { B59 } & \text { B75 } & : \\ \text { B37 } & \text { B51 } & \text { B60 } & \text { B76 } & : \\ \text { B40 } & \text { B52 } & \text { B61 } & \text { B78 } & : \\ \text { B41 } & \text { B53 } & \text { B62 } & \text { B82 } & : \\ \text { B44 } & \text { B54 } & & & :\end{array}$

M Leader Alleles

B7 $\quad$ B48

B8 B64

B14 B65

B38 B67

B39 B73

B42 B81

B

LEADER MATCH STATUS AND LEADER OF THE SHARED ALLELE

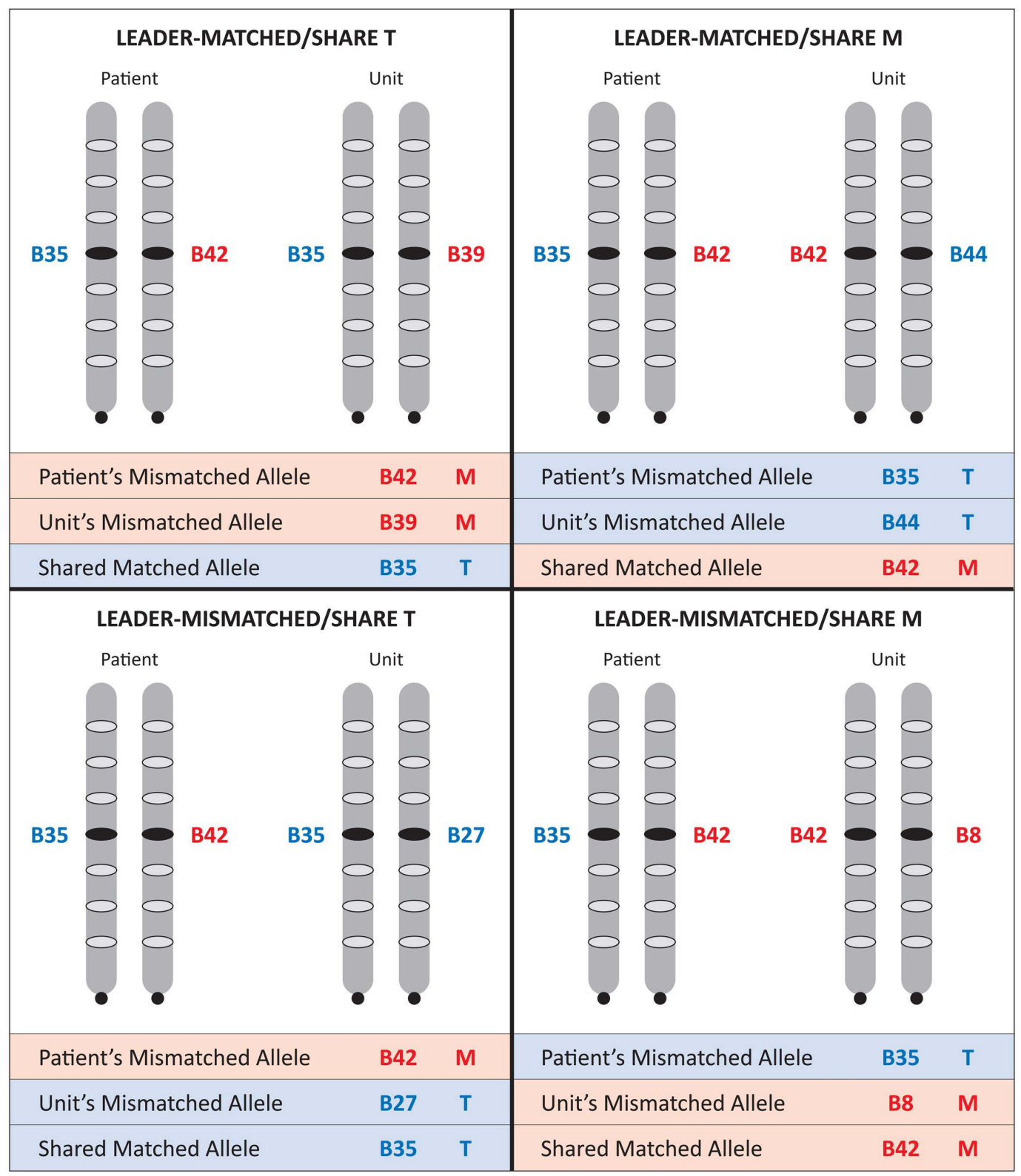

Figure 2. The dimorphic HLA-B leader is assigned to patients and cord blood units based on its one-to-one association with the HLA-B allele. (A) Each HLA-B allele is defined by its leader peptide. (B) Among patients and cord blood units with one HLA-B mismatch, the leader of the patient's and unit's mismatched alleles, and the leader of the matched shared allele is determined. Four groups are defined by the match status of the leader (leader-matched; leader-mismatched) and by the

leader of the shared allele (methionine [M] or threonine [T]). 
HLA-B alleles, ${ }^{28}$ the sheer number of polymorphisms presents a challenge in understanding the immunogenetic basis of transplant outcome. We surmised that if HLA-B alleles are described by two lineages, one family that encodes $\mathrm{M}$-leaders and one that encodes $\mathrm{T}$ leaders, that this dichotomy may aid the identification of HLA-B mismatches that influence GvHD and relapse. In CBT, HLA$\mathrm{C}$ and high-resolution matching influence clinical outcome. ${ }^{25-27} \mathrm{~A}$ limitation of the current analysis is the lack of HLA-C and high-resolution typing and although the basic principle that the leader informs cord blood transplant outcomes can be readily tested, the results of the current study require validation in an independent cohort.

We identified two potential associations between the HLA-B leader and cord blood outcomes among HLA-A, -DRB1-matched transplants with one HLA-B mismatch. First, as the number of M-leader(s) in the cord blood unit increased, the risk of relapse increased. Secondly, nonrelapse mortality was lower when the mismatched alleles were from different lineages and when the matched allele encoded an M leader than when the alleles were from the same lineage and the matched allele contributed a $T$ leader even after adjustment for various factors including the use of ATG. Interestingly, HLA-B leader genotype and matching did not definitively correlate with GvHD risk, and in this way, the impact of the leader on outcome differs between cord blood and unrelated donor transplantation. ${ }^{19,20}$ The associations of the HLA-B leader to outcome were observed among HLA-A and -DRB1-matched transplants with one HLA-B mismatch, and future validation of these findings in large independent populations is warranted.

The current study was not designed to identify the putative mechanisms of leader-associated effects on relapse and mortality and there many be several potential reasons for the different associations observed in CBT and unrelated donor transplantation. Unrelated transplantation and CBT procedures differ with respect to GvHD prophylaxis regimens as well as graft characteristics. GvHD has been reported to be lower in children who have received a cord blood or HLA-identical sibling bone marrow transplant. ${ }^{6}$ Similarly, the incidence of relapse and grades III-IV acute GvHD were lower in cord blood compared to matched or mismatched unrelated donor transplantation for leukemia. ${ }^{12}$ Compared to unrelated grafts, immature cord blood cells might be less likely activated during the alloreaction following transplant while NK-cell activation appears early after cord blood transplantation mitigating the risk of relapse. ${ }^{29}$ Possible mechanisms for higher relapse with lower non-relapse mortality among M-leader transplants could be related to the role of M-leader associated HLA ligands in both T-cell and NK-cell alloreactivity. M leaders influence inhibitory NK alloresponses. ${ }^{30,31}$ The exon 1 -encoded leader is physicially linked to exons 2 and 3 that define the peptide-binding region of HLA-B molecules, and the peptide-binding region of $\mathrm{M}$ leader linked allotypes have striking differences when compared to $T$ leader linked allotypes. Non-relapse mortality might include infectious causes of death for which both NK and T cells may play critical roles. NK surveillance in de novo and reactivation of viral infections after cord blood transplantation may shape relapse through the enhancement of NK maturation. ${ }^{32-36}$ We hypothesize that inhibitory NK responses involved in $M$ leader associated relapse might occur concurrently with T-cell recognition of viral or bacterial peptide/HLA-B complexes. These mechanisms could manifest as higher relapse with lower non-relapse mortality. Together with previous studies that have implicated NK KIR and HLA ligand interactions in relapse, ${ }^{8,18}$ the observations from the current study provide additional evidence for a potential role of the innate immune system in CBT outcomes. Future studies in double CBT may provide new information on key maternal-fetal interactions underpinning immune reactivity as a potential mechanism for the lower GvHD and relapse rates observed in CBT compared to adult hematopoietic stem cells.

Although recent data suggest that more comprehensive HLA matching between the patient and the cord blood unit is associated with improved outcomes, ${ }^{25,26,37}$ a major advantage of cord blood transplantation is the less stringent requirement for matching than is needed in unrelated donor transplantation. In this way, both cord blood transplantation and haploidentical transplantation significantly advance the availability of these curative modalities. The inherently low GvHD rates coupled with the ability to lower relapse through the judicious selection of cord blood units based on the HLA-B leader, enhances the curative potential of CBT and provides rationale to explore the leader in haploidentical transplantation.

The general clinical applicability of our findings to enhance CBT is facilitated by the one-to-one correlation of the leader to each serologically-defined HLA-B determinant, a feature that significantly simplifies the selection of mismatched units when matched units are not available, as the assignment of the leader requires only serologic-level definition of HLA-B. The observations from the current analysis suggest that when an MM or MT patient has multiple HLA-A, -DRB1-matched cord blood units, selection of leader-mismatched units with a shared $M$ leader allele may help to lower non-relapse mortality. The HLA-B leader might also have implications for NK immunotherapy. ${ }^{38-40}$ The frequencies of TT, MT and MM in cord blood units and patients in the current study, together with those observed in unrelated donor transplants and over 2 million US volunteer donors, suggest that patients will have choices.

\section{Disclosures}

EG reports grant from the Centre Scientifique de Monaco. EWP, TG, CM report grants from the National Institutes of Health. TG reports Kiadis Pharma and Regimmune. No other disclosures were reported.

\section{Contributions}

EWP and EG designed the study; EG, FV, CK, $A M, C M$, $S Q, V R, R T, C C, H R$ and $A R$ assembled the data; TG performed statistical analysis; EWP drafted the manuscript. All authors critically reviewed, edited the manuscript and approved the final version.

\section{Acknowledgments}

We are indebted to the clinical transplant teams who performed the transplants described in the study (Online Supplementary Table S1).

\section{Funding}

Supported by a grant to Eurocord (to EG) from the Centre Scientifique de Monaco; grants from the National Institutes of Health, USA (AI069197 to EWP, TG, CMK; CA100019 to EWP, TG, CMK; CA18029 to EWP and TG; CA72978 to EWP; CA015704 to TG). 


\section{References}

1. Gluckman E, Broxmeyer HA, Auerbach $\mathrm{AD}$, et al. Hematopoietic reconstitution in a patient with Fancon's anemia by means of umbilical-cord blood from an HLA-identical sibling. N Engl J Med. 1989; 321(17):1174-1178.

2. Broxmeyer HE, Douglas GW, Hangoc G, et al. Human umbilical cord blood as a potential source of transplantable hematopoietic stem/progenitor cells. Proc Natl Acad Sci U S A. 1989;86(10):3828-3832.

3. Wagner JE, Broxmeyer HE, Byrd RL, et al. Transplantation of umbilical cord blood after myeloablative therapy: analysis of engraftment. Blood. 1992;79(7):1874-1881.

4. Gluckman E, Rocha V, Boyer-Chammard A, et al. Outcome of cord-blood transplantation from related and unrelated donors. Eurocord Transplant Group and the European Blood and Marrow Transplantation Group. N Engl J Med. 1997;337(6):373-381

5. Rubinstein P, Carrier C, Scaradavou A, et al. Outcomes among 562 recipients of placental-blood transplants from unrelated donors. N Engl J Med. 1998;339(22):15651577.

6. Rocha V, Wagner JE, Sobocinski KA, et al. Graft-versus-host disease in children who have received a cord-blood or bone marrow transplant from an HLA-identical sibling. Eurocord and International Bone Marrow Transplant Registry Working Committee on Alternative Donor and Stem Cell Sources. N Engl J Med. 2000; 342(25):1846-1854.

7. Eapen M, Rubinstein P, Zhang MJ, et al. Outcomes of transplantation of unrelated donor umbilical cord blood and bone marrow in children with acute leukemia: a comparison study. Lancet. 2007; 369(9577):1947-1954.

8. Willemze R, Rodrigues CA, Labopin M, et al. KIR-ligand incompatibility in the graftversus-host direction improves outcomes after umbilical cord blood transplantation for acute leukemia. Leukemia. 2009; 23(3):492-500.

9. Brunstein CG, Wagner JE, Weisdorf DK, et al. Negative effect of KIR alloreactivity in recipients of umbilical cord blood transplant depends on transplantation conditioning intensity. Blood. 2009;113(22):56285634 .

10. Tanaka J, Morishima Y, Takahashi Y, et al. Effects of KIR ligand incompatibility on clinical outcomes of umbilical cord blood transplantation without ATG for acute leukemia in complete remission. Blood Cancer J. 2013;3(11):e164.

11. Barker JN, Boughan K, Dahi PB, et al. Racial disparities in access to HLA-matched unrelated donor transplants: a prospective 1312patient analysis. Blood Adv. 2019;3(7):939944.

12. Milano F, Gooley T, Wood B, et al. Cordblood transplantation in patients with minimal residual disease. N Engl J Med. 2016;375(10):944-953

13. Small TN, Papadopoulos EB, Boulad F, et al. Comparison of immune reconstitution after unrelated and related T-cell-depleted bone marrow transplantation: effect of patient age and donor leukocyte infusions. Blood. 1999;93(2):467-480.

14. Thomson BG, Robertson KA, Gowan D, et al. Analysis of engraftment graft-versushost disease, and immune recovery following unrelated donor cord blood transplantation. Blood. 2000;96(8):2703-2711

15. Ruggeri A, Peffault de Latour R, Carmagnat $M$, et al. Outcomes, infections, and immune reconstitution after double cord blood transplantation in patients with highrisk hematological diseases. Transpl Infect Dis. 2011;13(5):456-465.

16. Jacobson CA, Turki AT, McDonough SM, et al. Immune reconstitution after double cord blood stem cell transplantation comparison with unrelated peripheral blood stem cell transplantation. Biol Blood Marrow Transplant. 2012;18(4):565-574.

17. Garfall A, Kim HT, Sun L, et al. KIR ligand incompatibility is not associated with relapse reduction after double umbilical cord blood transplantation. Bone Marrow Transplant. 2013;48(7):1000-1002.

19. Sekine T, Marin D, Cao K, et al. Specific combinations of donor and recipient KIRHLA genotypes predict for large differences in outcome after cord blood transplantation. Blood. 2016;128(2):297-312.

19. Petersdorf E, Carrington M, O'hUigin C, et al. Role of HLA-B exon 1 in graft-versushost disease after unrelated haemopoietic cell transplantation: a retrospective cohort study. Lancet Haematol. 2020;7(1):e50-e60.

20. Petersdorf EW, Stevenson P, Bengtsson M, et al. HLA-B leader and survivorship after HLA-mismatched unrelated donor transplantation. Blood. 2020;136(3):362-369.

21. Horowitz A, Djaoud Z, Nemat-Gorgani N, et al. Class I HLA haplotypes form two schools that educate NK cells in different ways. Sci Immunol. 2016;1(3):eaag1672.

22. Braud V, Jones EY, McMichael A. The human major histocompatibility complex class Ib molecule HLA-E binds signal sequence-derived peptides with primary anchor residues at positions 2 and 9. Eur Immunol. 1997;27(5):1164-1169.

23. Merino AM, Song W, He D, et al. HLA-B signal peptide polymorphism influences the rate of HIV acquisition but not viral load. J Infect Dis. 2012;205(12):1797-1805.

24. Ramsuran V, Naranbhai V, Horowitz A, et al. Elevated HLA-A expression impairs HIV control through inhibition of NKG2Aexpressing cells Science, 2018. 359(6371):86-90. Erratum in: Science. August 2, 2019

25. Eapen M, Klein JP, Sanz GF, et al. Effect of donor-recipient HLA matching at HLA A, $\mathrm{B}, \mathrm{C}$, and DRB1 on outcomes after umbilical-cord blood transplantation for leukaemia and myelodysplastic syndrome: a retrospective analysis. Lancet Oncol. 2011:12(13):1214-1221.

26. Eapen $M$, Wang $T$, Veys PA, et al. Allelelevel HLA matching for umbilical cord blood transplantation for non-malignant diseases in children: a retrospective analysis. Lancet Haematol. 2017;4(7):e325-e333.

27. Rocha V, Gluckman E. Improving outcomes of cord blood transplantation: HLA match- ing, cell dose and other graft- and transplantation -related factors. Br J Haematol. 2009;147(2):262-274

28. HLA Informatics Group, The Anthony Nolan Research Institute. HLA nomenclature. http://hla.alleles.org/wmda/ index. html. Accessed March 6, 2020

29. Ando T, Tachibana T, Tanaka M, et al Impact of graft sources on immune reconstitution and survival outcomes following allogeneic stem cell transplantation. Blood Adv. 2020;4(2):408-419.

30. Luevano M, Daryouzeh M, Alnabhan R Querol S, Khakoo S, Madrigal A Saudemont A. The unique profile of cord blood natural killer cells balances incomplete maturation and effective killing function upon activation. Hum Immunol. 2012; 73(3):248-257.

31. Bjorkstrom NK, Riese P, Heuts F, et al Expression patterns of NKG2A, KIR, and CD57 define a process of CD56dim NKcell differentiation uncoupled from NK-cell education. Blood. 2010;116(19):3853-3864

32. Foley B, Cooley S, Verneris MR, et al Cytomegalovirus reactivation after allogeneic transplantation promotes a lasting increase in educated NKG2C+ natural killer cells with potent function. Blood. 2012;119(11):2665-2674.

33. Della Chiesa M, Falco M, Bertaina A, et al. Human cytomegalovirus infection promotes rapid maturation of $\mathrm{NK}$ cells expressing activating killer Ig-like receptor in patients transplanted with NKG2C-/ umbilical cord blood. J Immunol 2014;192(4):1471-1479.

34. Guma M, Angulo A, Vilches C, GomezLozano N, Malats N, Lopez-Botet M. Imprint of human cytomegalovirus infection on the NK cell receptor repertoire. Blood. 2004;104(12):3664-3671.

35. Elmaagacli AH, Steckel NK, Koldehoff M, et al. Early human cytomegalovirus replication after transplantation is associated with decreased relapse risk: evidence for a putative virus-versus-leukemia effect in acute myeloid leukemia patients. Blood. 2011;118(5):1402-1412.

36. Green ML, Leisenring WM, Xie $\mathrm{H}$, et al. CMV reactivation after allogeneic HCT and elapse risk: evidence for early protection in acute myeloid leukemia. Blood. 2013; 122(7):1316-1324.

37. Yokoyama H, Morishima Y, Fuji S, et al. Impact of HLA allele mismatch at HLA-A, $\mathrm{B},-\mathrm{C}$, and -DRB1 in single cord blood transplantation. Biol Blood Marrow Transplant. 2020;26(3):519-528

38. Knorr DA, Bachanova V, Verneris MR Miller JS. Clinical utility of natural killer cells in cancer therapy and transplantation. Semin Immunol. 2014:26(2):161-172.

39. Dahlberg CI, Sarhan D, Chrobok M, Duru $\mathrm{AD}$, Alici E. Natural killer cell-based therapies targeting cancer: possible strategies to gain and sustain anti-tumor activity. Front Immunol. 2015;6:605.

40. Liu E, Marin D, Banerjee P, et al. Use of CAR-transduced natural killer cells in CD19-positive lymphoid tumors. N Engl J Med. 2020;382(6):545-553. 